\title{
Evaluation of Vineyard Weeds as Potential Hosts of Black-Foot and Petri Disease Pathogens
}

C. Agustí-Brisach, D. Gramaje, M. León, J. García-Jiménez, and J. Armengol, Instituto Agroforestal Mediterráneo, Universidad Politécnica de Valencia, Camino de Vera s/n, 46022 Valencia, Spain

\begin{abstract}
Agustí-Brisach, C., Gramaje, D., León, M., García-Jiménez, J., and Armengol, J. 2011. Evaluation of vineyard weeds as potential hosts of blackfoot and Petri disease pathogens. Plant Dis. 95:803-810.

Weeds were sampled in grapevine rootstock mother fields, open-root field nurseries, and commercial vineyards of Albacete, Alicante, Castellón, Murcia, and Valencia provinces in Spain between June 2009 and June 2010 and evaluated as potential hosts of black-foot and Petri disease pathogens. Isolations were conducted in the root system and internal xylem tissues for black-foot and Petri disease pathogens, respectively. Cylindrocarpon macrodidymum was successfully isolated from the roots of 15 of 19 weed families evaluated and 26 of 52 weed species. Regarding Petri disease pathogens, one isolate of Phaeomoniella chlamydospora was obtained from Convolvulus arvensis, and

three isolates of Cadophora luteo-olivacea were obtained from Bidens subalternans, Plantago coronopus, and Sonchus oleraceus. Pathogenicity tests showed that Cylindrocarpon macrodidymum isolates obtained from weeds were able to induce typical black-foot disease symptoms. When inoculated in grapevines, isolates of Cadophora luteo-olivacea and Phaeomoniella chlamydospora were also shown to be pathogenic on grapevine cuttings. Our ability to recover grapevine pathogens from vineyard weeds and to demonstrate pathogenicity of recovered strains on grape suggests that these weeds may serve as a source of inoculum for infection of grapevine.
\end{abstract}

Over the last few years, an important decrease in the survival rate of grafted grapevines in nurseries and young vineyards worldwide has been noted (24). Fungi involved in wood decay are among the most destructive pathogens infecting grapevine propagation material, newly planted vines, and mature established vineyards. They have been reported in most grapevine-producing regions of the world and are responsible for the decline of young vines, loss of productivity, and young vine death $(25,35,37)$.

Young grapevine decline is caused by black-foot disease and Petri disease pathogens. Fungi associated with black-foot disease are Cylindrocarpon liriodendri J.D. MacDon. \& E.E. Butler, $C$. macrodidymum Schroers, Halleen \& Crous $(25,39,40)$, C. pauciseptatum Schroers \& Crous, Campylocarpon fasciculare Schroers, Halleen \& Crous, and C. pseudofasciculare Halleen, Schroers $\&$ Crous $(27,47)$. Petri disease is caused by Phaeomoniella chlamydospora (W. Gams, Crous, M.J. Wingf. \& Mugnai) Crous \& W. Gams, as well as several species of Phaeoacremonium W. Gams, Crous \& M.J. Wingf. $(35,36)$, with Phaeoacremonium aleophilum W. Gams, Crous, M.J. Wingf. \& Mugnai being the most commonly isolated and studied species of this genus (35). Several Phialophora-like and Acremonium spp. have also been involved in the decline of young vines, mainly species of the genus Cadophora Lagerberg \& Melin $(26,38)$. Among those, Cadophora luteo-olivacea (J.F.H. Beyma) T.C. Harr. \& McNew has been recently shown to be quite common on grapevines affected by esca and Petri disease in several viticultural areas worldwide $(1,23,26,33,44,46)$.

Field symptoms of black-foot and Petri disease-affected vines are frequently indistinguishable. External symptoms show stunted growth, reduced vigor, delayed or absence of spring growth, shortened internodes, sparse and chlorotic foliage with necrotic margins, wilting, and dieback $(17,41,48)$.

Specific symptoms of vines affected by Cylindrocarpon and Campylocarpon spp. often are sunken necrotic root lesions, with a

Corresponding author: J. Armengol, E-mail: jarmengo@eaf.upv.es

Accepted for publication 3 March 2011.

doi:10.1094/PDIS-12-10-0888

(C) 2011 The American Phytopathological Society reduction in root biomass and root hairs $(5,25)$. Removal of rootstock bark reveals black discoloration and necrosis of wood tissues which develops from the base of the rootstock, giving the disease the name of black-foot (25). Species of Cylindrocarpon are known to be saprobes in soil, occur on dead plant substrata, or act as weak pathogens of plants, infecting wounds of roots and stems of various hosts through wounds or openings $(25,47)$. The production of chlamydospores may allow Cylindrocarpon spp. to survive for extended periods in soil (27). However, very little information is currently available regarding the survival of these pathogens and the role that chlamydospores play during the infection processes (25).

Dissected vines affected by Petri disease show a typical black discoloration of the xylem vessels, which is a result of tyloses, gums, and phenolic compounds formed inside these vessels by the host in response to the fungus growing in and around the xylem vessels (36). Phaeomoniella chlamydospora is a soilborne pathogen due to its ability to produce chlamydospores in culture $(8,36,49)$. P. chlamydospora was detected in vineyard soil in New Zealand by nested polymerase chain reaction (PCR) (52) and in South Africa by species-specific PCR (13) and nested PCR (42). Ridgway et al. (43) used a nested PCR-restriction fragment length polymorphism (RFLP) procedure to determine the persistence of viable and nonviable spores of $P$. chlamydospora in soil and observed that nonviable spores were undetected after 8 weeks of being inoculated into dried soil, whereas viable spores still could be detected at 17 weeks after inoculation, indicating that spores could persist in soil and the inoculum could persist over time. Eskalen et al. (16) confirmed the presence of Phaeoacremonium aleophilum in soil by nested PCR. This species was also recovered from soil and standing water under grapevine drip systems (45).

Given these findings. soil is a source of inoculum for black-foot and Petri disease. Likewise, weeds could serve as potential hosts and, thus, be a source of inoculum for young vine decline. Weeds have been shown to be an alternative host for several plant pathogens $(54)$. Black et al. $(9,10)$ found a wide range of weed species as potential hosts for Diaporthe phaseolorum var. caulivora Kulik and Rhizoctonia solani J.G. Kühn AG-1 in soybean fields in Louisiana. Dissanayake et al. (15) isolated Pythium arrhenomanes Drechsler from roots of grass species native to the north central plains of North America. Cyperus rotundus L. and other weed species associated with peanut crop have also been identified as a host 
of Sclerotinia minor Jagger (31). Several weed plants in the genera Datura, Geranium, Ipomoea, and Solanum were found as weed hosts for Phytophthora infestans, while Portulaca oleracea L. was found as an alternative host for Phytophthora capsici (18).

The present work was conducted to study the role of weeds as potential hosts of black-foot and Petri disease pathogens in vineyards.

\section{Materials and Methods}

Field sites. In total, 32 fields ( 3 grapevine rootstock mother fields, 6 open-root field nurseries, and 23 commercial vineyards) were sampled between June 2009 and June 2010 in Albacete, Alicante, Castellón, Murcia, and Valencia provinces in east-central Spain (Fig. 1).

Sampling and fungal isolation. In each field, selected weed plants (three plants per species) were carefully dug out from the soil to keep the root system intact and taken back to the laboratory for immediate processing (Fig. 2). Roots of each plant were exposed by carefully washing the soil away. Roots were visually inspected for evidence of root necrosis, then cut open and examined for signs of discolored xylem vessels.

In order to isolate Cylindrocarpon spp., root sections were cut from necrotic areas, washed under running tap water, surface disinfested for $1 \mathrm{~min}$ in a $1.5 \%$ sodium hypochlorite solution, and washed twice with sterile distilled water. Small root pieces were plated on potato dextrose agar (PDA; Biokar-Diagnostics, Zac de Ther, France) supplemented with streptomycin sulfate (PDAS) at $0.5 \mathrm{~g} \mathrm{liter}^{-1}$ (Sigma-Aldrich, St. Louis). In order to recover Petri disease pathogens, isolations were made from sections $(10 \mathrm{~cm}$ long) that were cut from the basal stem and disinfected as previously described. Small pieces of internal healthy xylem tissues were plated on malt extract agar (MEA Oxoid Ltd., Basingstoke,
Hants, England) supplemented with streptomycin sulfate (MEAS) at $0.5 \mathrm{~g} \mathrm{liter}^{-1}$.

Plates were incubated for 10 to 15 days at $25^{\circ} \mathrm{C}$ in the dark and all colonies were transferred to PDA. Isolates were single-spored prior to morphological and molecular identification with the serial dilution method (14).

Fungal identification. Morphological identification. Species of Cylindrocarpon were identified by macroscopic characteristics including colony texture, color, and the shape of the growing margin on PDA. Conidial size was also measured on Spezieller Nährstoffarmer agar (SNA) with the addition of a 1-by-1-cm piece of filter paper to the colony surface (5).

Phaeomoniella chlamydospora was identified by conidiophore morphology, conidial size and shape, and its cultural characteristics (radial growth after 8 days at $25^{\circ} \mathrm{C}$, cardinal temperatures for growth and colony colors) on PDA and MEA (12). Cadophora luteo-olivacea was identified by conidiophore morphology, size of phialides and conidia, and cultural characteristics (radial growth after 8 days at $25^{\circ} \mathrm{C}$, cardinal temperatures for growth, colony colors, and pigment production) on MEA, PDA, and OA $(19,29)$.

DNA isolation and sequencing. Fungal mycelium and conidia from pure cultures grown on PDA for 2 to 3 weeks at $25^{\circ} \mathrm{C}$ in the dark were scraped and mechanically disrupted by grinding to a fine powder under liquid nitrogen using a mortar and pestle. Total DNA was extracted using the E.Z.N.A. Plant Miniprep Kit (Omega Biotek, Doraville, USA) following the manufacturer's instructions. DNA was visualized on $0.7 \%$ agarose gels stained with ethidium bromide and was stored at $-20^{\circ} \mathrm{C}$.

Identification of Cylindrocarpon spp. was confirmed by a multiplex PCR system using a set of three pairs of specific primers (3). $P$. chlamydospora was detected by PCR using specific primers Pch1-Pch2 (50). Identification of $C$. luteo-olivacea isolates was

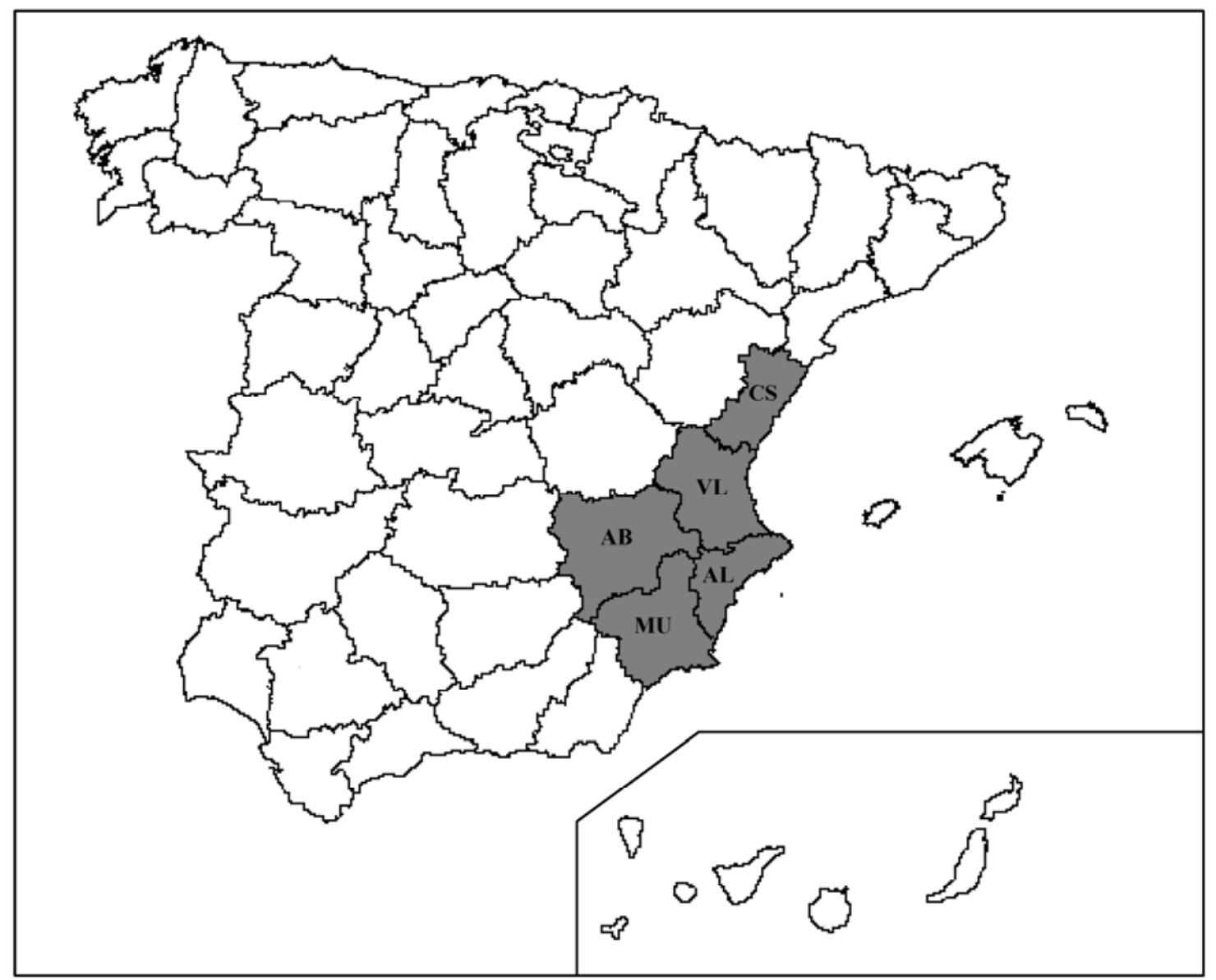

Fig. 1. Geographic location of the Spanish provinces from which grapevine rootstock mother fields, open-root field nurseries, and commercial vineyards were sampled. Twoletter code indicates the name of the province: AB (Albacete), AL (Alicante), CS (Castellón), MU (Murcia), and VL (Valencia). 
confirmed by analysis of the internal transcribed spacer (ITS) region of rDNA amplified using the fungal universal primers ITS1F and ITS4 (20). PCR products were purified with the High Pure PCR Product Purification Kit (Roche Diagnostics, Mannheim,
Germany) and sequenced in both directions by Macrogen Inc. (Seoul, Republic of Korea).

Pathogenicity tests. Ten Cylindrocarpon macrodidymum isolates obtained from different weed species were selected to com-
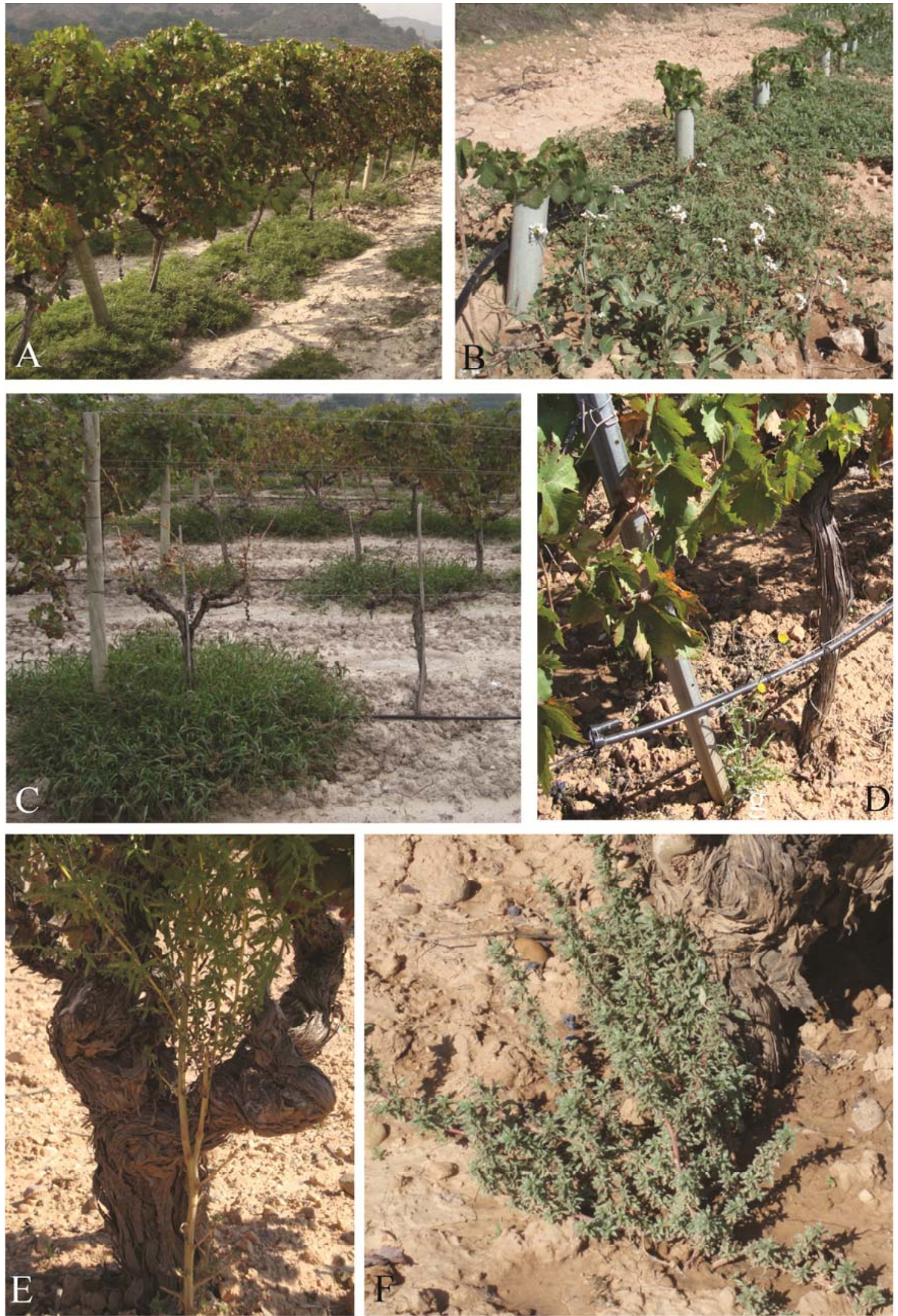

Fig. 2. Weed species in grapevine rootstock mother fields, open-root field nurseries, and commercial vineyards. A, Several weed species growing in a commercial vineyard; B, Amaranthus blitoides and Diplotaxis erucoides in a young vineyard and weeds growing close to grapevine plants; C, Echinocloa crus-galli; D, Sonchus oleraceus; E, Bassia scoparia; and F, Amaranthus blitoides. 
plete Koch's postulates on grapevines (Tables 1 and 2). Inoculum was produced on wheat (Triticum aestivum L.) seed (11). Seed were soaked for $12 \mathrm{~h}$ in distilled water, air dried, and transferred to $300-\mathrm{ml}$ flasks. Each flask was autoclaved three times on three successive days at $120^{\circ} \mathrm{C}$ for $1 \mathrm{~h}$. Two fungal disks of a 2-week-old culture of each C. macrodidymum isolate grown on PDA at $25^{\circ} \mathrm{C}$ were placed aseptically in separate flasks. The flasks were incubated at $25^{\circ} \mathrm{C}$ for 4 weeks, and shaken once a week to avoid clustering of inoculum.

Plastic pots $\left(220 \mathrm{~cm}^{3}\right)$ were filled with a mixture of sterilized peat moss and $10 \mathrm{~g}$ of inoculum per pot. Seedlings obtained from 'Palomino' grapevines were planted individually in each pot at the two-true-leaf stage. Controls were inoculated with sterile uninoculated seed. Six replicates (each one in individual pots) for each isolate were used, with an equal number of control plants. After inoculation, plants were placed in a greenhouse at 25 to $30^{\circ} \mathrm{C}$ in a completely randomized design and watered every 3 days or as needed.

Forty-five days after inoculation, plants were observed for the development of foliar symptoms and evaluated using a 0-to-5 rating scale, where $0=$ no symptoms; $1=1$ to $25,2=26$ to $50,3=51$ to 75 , and $4=76$ to $100 \%$ chlorotic and necrotic leaves; and $5=$ dead plant. Plants were gently uprooted and washed free of soil. Root symptoms of individual plants were evaluated on the following scale: $0=$ healthy, with no lesions; $1=$ slight discoloration, with 0 to $25 \%$ of root mass reduction; $2=$ discoloration, with 26 to $50 \%$ of root mass reduction; $3=$ moderate discoloration, with 51 to $75 \%$ of root mass reduction; $4=$ severe discoloration, with $>75 \%$ of root mass reduction; and $5=$ dead plant. In addition, dry weights of shoot and root were recorded for each plant. Symptomatic roots were aseptically plated on MEAS in an attempt to reisolate $C$. macrodidymum and complete Koch's postulates. The experiment was repeated.

Table 1. Weed families and species surveyed as potentials hosts of Cylindrocarpon spp., indicating those from which Cylindrocarpon macrodidymum was isolated

\begin{tabular}{|c|c|c|c|}
\hline Family & Species & Frequency of positive fields ${ }^{y}$ & Frequency of positive plants $\mathrm{z}$ \\
\hline \multirow[t]{4}{*}{ Amaranthaceae } & Amaranthus blitoides & $3 / 7$ & $6 / 9$ \\
\hline & Amaranthus blitum & $0 / 3$ & $\ldots$ \\
\hline & Amaranthus retroflexus & $1 / 4$ & $1 / 3$ \\
\hline & Salsola kali & $1 / 6$ & $1 / 3$ \\
\hline Ambrosiaceae & Xanthium stromarium & $1 / 1$ & $3 / 3$ \\
\hline \multirow[t]{12}{*}{ Asteraceae } & Aster alpinus & $0 / 1$ & . \\
\hline & Bidens subalternans & $1 / 1$ & $3 / 3$ \\
\hline & Centaurea cyanus & $0 / 1$ & \\
\hline & Cirsium arvense & $1 / 3$ & $3 / 3$ \\
\hline & Conyza bonariensis & $0 / 5$ & $\ldots$ \\
\hline & Conyza canadiensis & $0 / 1$ & $\ldots$ \\
\hline & Helichrysum stoechas & $1 / 1$ & $3 / 3$ \\
\hline & Picnomom acarna & $0 / 2$ & \\
\hline & Senecio vulgaris & $2 / 2$ & $4 / 6$ \\
\hline & Sonchus asper & $0 / 1$ & $\ldots$ \\
\hline & Sonchus oleraceus & $4 / 10$ & $9 / 12$ \\
\hline & Sonchus terrenimus & $3 / 5$ & $6 / 9$ \\
\hline Boraginaceae & Heliotropium europaeum & $0 / 5$ & $\ldots$ \\
\hline \multirow[t]{3}{*}{ Brassicaceae } & Descurainia sophia & $0 / 1$ & $\ldots$ \\
\hline & Diplotaxis erucoides & $1 / 8$ & $2 / 3$ \\
\hline & Hirschfeldia incana & $1 / 1$ & $3 / 3$ \\
\hline \multirow[t]{5}{*}{ Chenopodiaceae } & Atriplex hortensis & $0 / 2$ & $\ldots$ \\
\hline & Bassia scoparia & $1 / 2$ & $2 / 3$ \\
\hline & Chenopodium glaucum & $0 / 1$ & $\ldots$ \\
\hline & Chenopodium murale & $3 / 9$ & $6 / 9$ \\
\hline & Kochia scoparia & $0 / 1$ & \\
\hline Convolvulaceae & Convolvulus arvensis & $2 / 2$ & $1 / 6$ \\
\hline Cyperaceae & Cyperus rotundus & $0 / 2$ & $\ldots$ \\
\hline \multirow[t]{4}{*}{ Euphorbiaceae } & Chamaesyce serpens & $0 / 1$ & $\ldots$ \\
\hline & Chrozophora tinctoria & $1 / 1$ & $2 / 3$ \\
\hline & Euphorbia segetalis & $2 / 2$ & $4 / 6$ \\
\hline & Euphorbia serrata & $0 / 2$ & $\ldots$ \\
\hline Fumariaceae & Fumaria officinalis & $0 / 1$ & $\ldots$ \\
\hline Geraniaceae & Erodium malacoides & $1 / 2$ & $2 / 3$ \\
\hline Leguminosae & Medicago lupulina & $1 / 1$ & $3 / 3$ \\
\hline \multirow[t]{2}{*}{ Liliaceae } & Allium oleraceum & $1 / 1$ & $1 / 3$ \\
\hline & Asparagus acutifolius & $0 / 1$ & $\ldots$ \\
\hline \multirow[t]{2}{*}{ Malvaceae } & Lavatera cretica & $1 / 1$ & $3 / 3$ \\
\hline & Malva neglecta & $0 / 1$ & \\
\hline \multirow[t]{2}{*}{ Plantaginaceae } & Plantago coronopus & $1 / 1$ & $3 / 3$ \\
\hline & Plantago lanceolata & $0 / 1$ & $\ldots$ \\
\hline \multirow[t]{6}{*}{ Poaceae } & Bromus madritensis & $1 / 1$ & $1 / 3$ \\
\hline & Bromus rubens & $0 / 1$ & $\ldots$ \\
\hline & Echinocloa crus-galli & $2 / 3$ & $2 / 6$ \\
\hline & Hordeum leporinum & $0 / 1$ & $\ldots$ \\
\hline & Leptochloa uninervia & $0 / 1$ & $\ldots$ \\
\hline & Piptatherum miliaceum & $0 / 1$ & $\ldots$ \\
\hline & Portulaca oleracea & $1 / 3$ & $1 / 3$ \\
\hline \multirow[t]{2}{*}{ Solanaceae } & Datura inoxia & $0 / 2$ & $\ldots$ \\
\hline & Solanum nigrum & $1 / 2$ & $3 / 3$ \\
\hline \multirow[t]{2}{*}{ Umbelliferae } & Pimpinella anisum & $0 / 1$ & $\ldots$ \\
\hline & Ridolfia segetum & $0 / 1$ & $\ldots$ \\
\hline
\end{tabular}

\footnotetext{
${ }^{y}$ Number of fields from which C. macrodidymum was isolated/number of total fields in which the weed species was collected.

${ }^{\mathrm{z}}$ Number of plants from which $C$. macrodidymum was isolated/number of total plants collected in positive fields (three plants per field).
} 
Shoot and root disease severities were calculated using the McKinney's index (34), which expresses the percentage of the maximum disease severity according to the formula $\mathrm{MI}=[\Sigma(R \times$ $N)] \times 100 / H \times T$, where $R=$ disease rating, $N=$ number of plants with this rating, $H=$ the highest rating, and $T=$ total number of plants counted. Statistical analysis of the results was done using one-way analysis of variance (ANOVA) with treatment as independent variable and the following dependant variables: shoot disease severity (percent), shoot dry weight (in grams), root disease severity (percent), and root dry weight (in grams). The Student's least significant difference (LSD) test was used to compare the overall means of each treatment at $P<0.05$. Statistical analyses were performed using Statistical Analysis System (SAS, version 9.0; SAS Institute Inc. Cary, NC).

One isolate of $P$. chlamydospora (Pch-256) obtained from Convolvulus arvensis $\mathrm{L}$. and two isolates of Cadophora luteo-olivacea (Clo-65 and Clo-66) obtained from Bidens subalternans DC. and Sonchus oleraceus L., respectively, were used. Pathogenicity tests were conducted in 1-year-old grapevine cuttings of 110 Richter rootstock, as described by Gramaje et al. (23). Dormant cuttings were cut into uniform lengths containing four to five buds, and then hot-water treated at $53^{\circ} \mathrm{C}$ for $30 \mathrm{~min}$ to eliminate the possible incidence of fungal trunk pathogens (21). In order to enhance callusing and rooting, dormant cuttings were buried into sterilized peat moss in plastic boxes and placed in a callusing room at $25^{\circ} \mathrm{C}$ and $100 \%$ humidity for 4 weeks. After callusing and rooting, cuttings were wounded between the two upper internodes with a 5$\mathrm{mm}$ cork borer. A 5-mm mycelium agar plug from a 2-week-old culture was placed in the wound. Wounds were wrapped with Parafilm. Eight cuttings per fungal isolate were used. Additionally, eight cuttings were inoculated with 5-mm noncolonized PDA agar plugs from two different plates for negative controls. Inoculated cuttings were planted immediately in individual pots, placed in a greenhouse at $25^{\circ} \mathrm{C}$, and watered every 3 days. Plants were arranged in a completely randomized design. The experiment was repeated.

Cuttings were collected after 14 weeks and inspected for lesion development. Extent of vascular discoloration was measured upward and downward from the inoculation point. Small pieces $(0.5$ to $1 \mathrm{~cm}$ ) of necrotic tissue from the edge of each lesion were cut and placed on MEAS in an attempt to recover the inoculated fungi and complete Koch's postulates. Fungi were identified as previously described.

Lesion length data were subjected to analyses of variance using SAS and the LSD test was calculated at the 5\% significance level to compare the treatment means for the different fungal species.

\section{Results}

Isolation and identification of fungal species from weeds. No xylem necroses were observed in all weed plant samples but roots showed slight discolorations or necrotic lesions.

Cylindrocarpon spp. were isolated from roots of weeds in 17 of the 32 field sites surveyed, including all type of fields (3 grapevine rootstock mother fields, 3 open-root field nurseries, and 11 commercial vineyards) and in all provinces. All Cylindrocarpon isolates were identified by multiplex PCR as Cylindrocarpon macrodidymum, because they generated a product size of $387 \mathrm{bp}$ characteristic of this species (Fig. 3). The families and species of weeds from which $C$. macrodidymum was isolated are shown in Table 1. This pathogen was recovered from 15 of 19 weed families evaluated and 26 of 52 species. In each family, the number of host weed species was variable. The family Asteraceae was the most prevalent, with six weed species hosting $C$. macrodidymum, followed by Amaranthaceae (three species) and Brassicaceae, Chenopodiaceae, Euphorbiaceae, and Poaceae (two species each). C. macrodidymum was isolated from only one weed species in the remaining families (Ambrosiaceae, Convolvulaceae, Geraniaceae, Leguminosae, Liliaceae, Malvaceae, Plantaginaceae, Portulacaceae, and Solanaceae). The frequency of isolation of C. macrodidymum was very variable depending on the number of field sites or plants evaluated for each weed species (Table 1).

Only one isolate of $P$. chlamydospora was obtained from Convolvulus arvensis in a grapevine commercial field. Three isolates of Cadophora luteo-olivacea were obtained from B. subalternans (in a grapevine rootstock mother field) and from Plantago coronopus L. and S. oleraceus (both in an open-root field nursery).

Pathogenicity tests. Data of the two Cylindrocarpon macrodidymum pathogenicity tests were combined because of the lack of significant differences between the two tests for all studied variables: shoot disease severity $(F=0.04 ; \mathrm{df}=1 ; P=0.8390)$, shoot dry weight $(F=0.27 ; \mathrm{df}=1 ; P=0.6064)$, root disease severity $(F$ $=0.20 ; \mathrm{df}=1 ; P=0.6595)$, and root dry weight $(F=0.07 ; \mathrm{df}=1$; $P=0.7941)$. All isolates used in this study were pathogenic to seedlings obtained from Palomino grapevines. First symptoms were observed 10 days after inoculation and consisted in reduced vigor, leaves with internervial chlorosis and necrosis, necrotic root lesions with a reduction in root biomass, and death of some plants at the end of the 45-day incubation period. Inoculation with $C$.

Table 2. Pathogenicity of Cylindrocarpon macrodidymum isolates obtained from 12 different weed species to seedlings of 'Palomino' grapevine 45 days after inoculation $^{\mathrm{X}}$

\begin{tabular}{|c|c|c|c|c|c|}
\hline \multirow[b]{2}{*}{ Isolates } & \multirow[b]{2}{*}{ Weed species } & \multicolumn{2}{|c|}{ Shoot $^{y}$} & \multicolumn{2}{|c|}{$\operatorname{Root}^{z}$} \\
\hline & & Disease severity & Dry weight (g) & Disease severity & Dry weight (g) \\
\hline MH-1 & Salsola kaly & $68.3 \mathrm{a}$ & $0.18 \mathrm{~b}$ & $68.8 \mathrm{~b}$ & $0.20 \mathrm{~b}$ \\
\hline MH-3 & Echinocloa crus-galli & 83.3 bcde & $0.05 \mathrm{cdef}$ & $76.7 \mathrm{bc}$ & $0.07 \mathrm{~cd}$ \\
\hline МH-9 & Sonchus oleraceus & 80.0 bcde & 0.08 bcdef & $68.8 \mathrm{~b}$ & $0.16 \mathrm{bc}$ \\
\hline MH-11 & Euphorbia segetalis & 88.3 cde & 0.03 ef & $83.3 \mathrm{bc}$ & $0.01 \mathrm{~d}$ \\
\hline MH-21 & Amaranthus blitoides & $66.7 \mathrm{~b}$ & 0.12 bcde & $70.0 \mathrm{~b}$ & $0.10 \mathrm{bcd}$ \\
\hline MH-25 & Chenopodium murale & 86.7 bcde & 0.06 cdef & $79.6 \mathrm{bc}$ & $0.08 \mathrm{~cd}$ \\
\hline MH-29 & Bassia scoparia & $73.3 \mathrm{bcd}$ & 0.08 cdef & $81.3 \mathrm{bc}$ & $0.10 \mathrm{bcd}$ \\
\hline MH-34 & Chrozophora tinctoria & $75.0 \mathrm{bcd}$ & $0.14 b c$ & $79.2 \mathrm{bc}$ & $0.17 \mathrm{bc}$ \\
\hline MH-42 & Convolvulus arvensis & $91.7 \mathrm{de}$ & $0.05 \mathrm{def}$ & $86.7 \mathrm{bc}$ & $0.06 \mathrm{~cd}$ \\
\hline МH-44 & Hellychrisum stoechas & $76.7 \mathrm{bcd}$ & 0.08 cdef & $83.3 \mathrm{bc}$ & $0.07 \mathrm{~cd}$ \\
\hline MH-46 & Diplotaxis erucoides & $100.0 \mathrm{e}$ & $0.02 \mathrm{f}$ & $91.7 \mathrm{bc}$ & $0.01 \mathrm{~d}$ \\
\hline MH-55 & Sonchus terrenimus & $66.7 \mathrm{~b}$ & $0.13 \mathrm{bcd}$ & $70.0 \mathrm{~b}$ & $0.14 b c$ \\
\hline Control & $\ldots$ & $0.00 \mathrm{a}$ & $0.74 \mathrm{a}$ & $16.7 \mathrm{a}$ & $0.68 \mathrm{a}$ \\
\hline
\end{tabular}

$x$ Values represent the means of 12 replications for each isolate; six per experiment. Analysis of variance: means in a column followed by the same letter are not significantly different according to Student's least significant difference test at $P<0.05$.

y Shoot symptoms were evaluated on the following scale: $0=$ no symptoms; $1=1$ to $25,2=26$ to $50,3=51$ to 75 , and $4=76$ to $100 \%$ chlorotic and necrotic leaves; and $5=$ dead plant. Shoot disease severity was calculated using the McKinney's index: $\mathrm{MI}=[\Sigma(R \times N)] \times 100 / H \times T$, where $R=$ disease rating, $N=$ number of plants with this rating, $H=$ the highest rating, and $T=$ total number of plants counted.

${ }^{\mathrm{z}}$ Roots symptoms were evaluated on the following scale: $0=$ healthy, with no lesions; $1=$ slight discoloration, with 0 to $25 \%$ of root mass reduction; $2=$ discoloration, with 26 to $50 \%$ of root mass reduction; $3=$ moderate discoloration, with 51 to $75 \%$ of root mass reduction; $4=$ severe discoloration, with $>75 \%$ of root mass reduction; and $5=$ dead plant. Root disease severity was calculated using the McKinney's index. 
macrodidymum isolates had a significant effect on all variables (one-way ANOVA: shoot disease severity, $F=14.39$; $\mathrm{df}=12 ; P<$ 0.001 ; shoot dry weight, $F=33.59$; df $=12$; $P<0.001$; root disease severity, $F=13.48$; df $=12 ; P<0.001$; and root dry weight, $F$ $=17.47 ; \mathrm{df}=12 ; P<0.001)$. All isolates caused a significant increase of shoot and root disease severity and a decrease of shoot and root dry weight when compared with the uninoculated controls. The isolate MH-46 was the most virulent, causing $100 \%$ mortality of grapevine seedlings at the end of the 45-day incubation period (Table 2).

Similar effects were obtained in the two experiments of lesion length caused by Petri disease pathogens $(F=2.99$; df $=1 ; P=$ $0.0894)$; thus, the data were combined in a single analysis. ANOVA of the lesion length data on grapevine cuttings indicated a significant treatment effect $(F=201.47$; df $=3 ; P<0.001)$. According to the LSD test at $P<0.05$ (LSD = 16.4), Phaeomoniella chlamydospora isolate Pch-256 (mean $57.1 \mathrm{~mm}$ ) and Cadophora luteo-olivacea isolates Clo-65 $(66.3 \mathrm{~mm})$ and Clo-66 $(65.5 \mathrm{~mm})$ caused lesions on the xylem of grapevine cuttings that were significantly longer than the controls (mean $3.9 \mathrm{~mm}$ ).

\section{Discussion}

This is the first study to examine weeds as potential hosts for black-foot and Petri disease pathogens on grapevine fields. Cylindrocarpon macrodidymum was commonly isolated from weeds collected in grapevine rootstock mother fields, open-root field nurseries, and commercial vineyards, whereas only one isolate of P. chlamydospora and three isolates of Cadophora luteo-olivacea were recovered.

This study shows a high rate of isolation of Cylindrocarpon macrodidymum from roots of weeds collected in grapevine fields. Although several species of Cylindrocarpon have been identified worldwide as a common cause of vine death in nurseries and in young vineyards $(25,47)$, only C. macrodidymum was found in the present study. This is in agreement with the results obtained by Alaniz et al. (5), who reported C. macrodidymum as the predominant species in all grapevine-growing regions in Spain. To date, $C$. macrodidymum had been shown to be species specific to grapevines, being isolated only from young grapevines in Australia (51), California (39,40,48), Chile (7), New Zealand (27), South Africa (27), Spain (5), and Uruguay (2) but not from other hosts. There was variation among weed families and species in the percentage of plants colonized by $C$. macrodidymum and its field frequency. This variation could affect their importance as alternative hosts as described for weed hosts of Pythium arrhenomanes in sugarcane fields by Dissanayake et al. (15) but further research is needed to determine whether $C$. macrodidymum has a preference for some weed families or species.
Cylindrocarpon spp. are soilborne pathogens which produce chlamydospores to survive for extended periods of time in the soil (25). However, very little information is currently available regarding the long-term survival of the species of this genus $(11,25)$. The high frequency of isolation of $C$. macrodidymum obtained in this study demonstrates that this species may have the ability to alternatively survive in weeds.

The vascular pathogens Cadophora luteo-olivacea and Phaeomoniella chlamydospora were also isolated from several weeds within grapevine fields but in a very small percentage compared with Cylindrocarpon macrodidymum. Recently, Cadophora luteo-olivacea has been identified in grapevines showing decline symptoms in California (46), South Africa (26), Uruguay (1), New Zealand (33), Northeastern America (44), and Spain (23). This work represents the first report of $P$. chlamydospora on a host different from grapevine. $P$. chlamydospora is regarded as the most important fungal organism associated with Petri disease because of its predominance in affected grapevines $(35,43)$; therefore, although only one isolate was recovered, this finding could indeed be a very important aspect to consider in further epidemiological studies of this species.

In contrast with Cylindrocarpon macrodidymum, Cadophora luteo-olivacea and P. chlamydospora were isolated from asymptomatic xylem tissues. In similar studies, weeds also have been found to be symptomless hosts for other plant pathogens, such as $R$. solani and D. phaseolorum var. caulivora in soybean $(9,10)$. Our results could indicate that $C$. luteo-olivacea and $P$. chlamydospora may be surviving in weeds as endophytes. The potential role of these pathogens as grapevine endophytes and the erratic manifestation of leaf symptoms in infected grapevines have been previously reported by different authors. Whiting et al. (53) suggested that $P$. chlamydospora and Phaeoacremonium spp. may exist as endophytes or as latent infections in vine tissue and elicit plant response only when vines are stressed. Infected grapevine rootstock mother plants with no external foliar symptoms were reported by Fourie and Halleen (17) and Aroca et al. (6). Halleen et al. (28) observed that primary pathogens associated with young vine decline in South Africa, such as P. chlamydospora, Phaeoacremonium aleophilum, and $C$. luteo-olivacea were already present in the apparently healthy rootstock propagation material as endophytes or latent pathogens. Despite the isolation of Phaeoacremonium spp. and Phaeomoniella chlamydospora from wood discoloration of young grapevines, Zanzotto et al. (55) did not observe classic foliar symptoms of either Petri disease or esca in the vineyards during the 4 years after planting. Gramaje et al. (22), who inoculated five species of Phaeoacremonium, $P$. chlamydospora, and C. luteo-olivacea on rootstock cuttings under field conditions, observed that these species were not able to cause foliar symptoms on inoculated plants during the grapevine growing season.

\section{$\begin{array}{lllllllllllllllllllll}M & 1 & 2 & 3 & 4 & 5 & 6 & 7 & 8 & 9 & 10 & 11 & 12 & 13 & 14 & 15 & 16 & 17 & 18 & 19 & M\end{array}$}

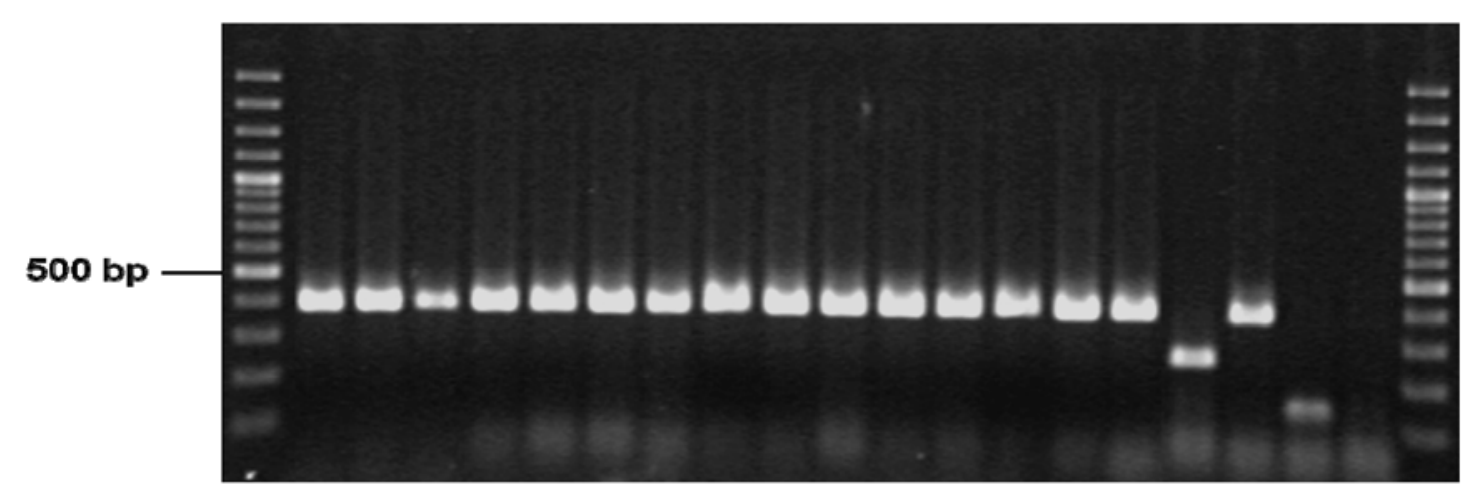

Fig. 3. Identification of Cylindrocarpon macrodidymum isolates obtained from roots of weeds by polymerase chain reaction (PCR). PCR amplification products with three primer pairs: Mac1/MaPa2, Lir1/Lir2, and Pau1/MaPa2. Lanes 1-15, isolates from Amaranthus blitoides (lanes 6 and 13), Amaranthus retroflexus (lane 12), Bassia scoparia (lane 2), Chrozophora tinctoria (lanes 3, 4, and 7), Cirsium arvense (lane 10), Convolvulus arvensis (lanes 11 and 14), Diplotaxis erucoides (lane 9), Hellycrysum stoechas (lane 15), Solanum nigrum (lanes 5 and 8), and Sonchus oleraceus (lane 1); lanes 16-18, positive control of Cylindrocarpon liriodendri, C. macrodidymum, and C. pauciseptatum, respectively; lane 19, negative control; lane M, 100-bp DNA ladder. 
Pathogenicity tests showed that Cylindrocarpon macrodidymum isolates obtained from weeds were able to induce typical black foot disease symptoms and caused shoot and root mass reduction on grapevine seedlings. Different levels of virulence were also observed in the $C$. macrodidymum isolates inoculated. These results are in agreement with those obtained by Alaniz et al. (4), who detected a relevant genetic and virulence diversity in $C$. macrodidymum by inter-simple-sequence repeat analysis and pathogenicity tests. Isolates of Cadophora luteo-olivacea and P. chlamydospora were also shown to be pathogenic on grapevine cuttings. The expression of symptoms caused by $P$. chlamydospora and C. luteoolivacea on grapevines has been extensively investigated and successfully reproduced with artificial inoculations under field $(22,26,36)$ or greenhouse conditions $(23,26,32,55)$.

Our ability to recover grapevine pathogens from vineyard weeds and to demonstrate pathogenicity of recovered strains on grape suggests that these weeds may serve as a source of inoculum for infection of grapevine. These weed species are among the most common and widely distributed in Spanish vineyards (30). Sampling of weeds prevalent in other viticultural regions in different countries might reveal a larger host range for them and contribute to determining whether they are likely to play an important role in maintaining or increasing the inoculum density of the pathogens in grapevine fields. In Spanish vineyards, weeds are often well managed during the growing season. During the off-season, when land is fallow, weeds are not managed and their population size increases. Large populations of host weed species may increase the amount of infected plant debris in grapevine fields and, thus, contribute to elevate inoculum levels the following spring. These results emphasize the importance of weed control programs in possibly reducing the inoculum levels of soilborne pathogens.

\section{Acknowledgments}

This research was financially supported by the projects RTA2007-00023C04-03 and RTA2010-00009-C03-03 (Instituto Nacional de Investigación y Tecnología Agraria y Alimentaria, INIA, Spain) and the European Regional Development Fund (ERDF). We thank A. Rustignoli and V. Garrigues for technical assistance and R. Raposo for providing valuable advice on the writing of this manuscript.

\section{Literature Cited}

1. Abreo, E., Lupo, S., Martínez, I., and Bettucci, L. 2008. Fungal species associated to grapevine trunk diseases in Uruguay. J. Plant Pathol. 90:591.

2. Abreo, E., Martínez, S., Bettucci, L., and Lupo, S. 2010. Morphological and molecular characterization of Campylocarpon and Cylindrocarpon spp. associated with black foot disease of grapevines in Uruguay. Australas. Plant Pathol. 39:446-452.

3. Alaniz, S., Armengol, J., García-Jiménez, J., Abad-Campos, P., and León, M. 2009. A multiplex PCR system for the specific detection of Cylindrocarpon liriodendri, C. macrodidymum, and C. pauciseptatum from grapevine. Plant Dis. 93:821-825.

4. Alaniz, S., Armengol, J., León, M., García-Jiménez, J., and Abad-Campos, P. 2009. Analysis of genetic and virulence diversity of Cylindrocarpon liriodendri and $C$. macrodidymum associated with black foot disease of grapevine. Mycol. Res. 113:16-23.

5. Alaniz, S., Leon, M., García-Jiménez, J., Abad, P., and Armengol, J. 2007. Characterization of Cylindrocarpon species associated with black foot disease of grapevine in Spain. Plant Dis. 91:1187-1193.

6. Aroca, A., Gramaje, D., Armengol, J., García-Jiménez, J., and Raposo, R. 2010. Evaluation of the grapevine nursery propagation process as a source of Phaeoacremonium spp. and Phaeomoniella chlamydospora and occurrence of trunk disease pathogens in rootstock mother vines in Spain. Eur. J. Plant Pathol. 126:165-174.

7. Auger, J., Esterio, M., and Pérez, I. 2007. First report of black foot disease of grapevine caused by Cylindrocarpon macrodidymum in Chile. Plant Dis. 91:470.

8. Bertelli, E., Mugnai, L., and Surico, G. 1998. Presence of Phaeoacremonium chlamydosporum in apparently healthy rooted grapevine cuttings. Phytopathol. Mediterr. 37:79-82.

9. Black, B. D., Griffin, J. L., Russin, J. S., and Snow, J. P. 1996. Weed hosts for Rhizoctonia solani, causal agent for Rhizoctonia foliar blight of soybean (Glycine max). Weed Technol. 10:865-869.

10. Black, B. D., Padgett, G. B., Russin, J. S., Griffin, J. L., Snow, J. P., and Berggren, G. T., Jr. 1996. Potential weed hosts for Diaporthe phaseolorum var. caulivora, causal agent for soybean stem canker. Plant Dis. 80:763-765.

11. Brayford, D. 1993. Cylindrocarpon. Pages 103-106 in: Methods for Research on Soilborne Phytopathogenic Fungi. L. L. Singleton, J. D. Mihail, and C. M. Rush, eds.. American Phytopathological Society, St. Paul, MN.

12. Crous, P. W., and Gams, W. 2000. Phaeomoniella chlamydospora gen. et comb. nov., a causal organism of petri grapevine decline and esca. Phytopathol. Mediterr. 39:112-188.

13. Damm, U., and Fourie, P. H. 2005. A cost-effective protocol for molecular detection of fungal pathogens in soil. S. Afr. J. Sci. 101:135-139.

14. Dhingra, O. D., and Sinclair, J. B. 1995. Basic Plant Pathology Methods, 2nd ed. CRC Press, Boca Raton, FL.

15. Dissanayake, N., Hoy, J. W., and Griffin, J. L. 1997. Weed hosts of the sugarcane root rot pathogen, Pythium arrhenomanes. Plant Dis. 81:587591.

16. Eskalen, A., Rooney, S. N., and Gubler, W. D. 2001. Detection of Phaeomoniella chlamydospora and Phaeoacremonium spp. from soil and host tissue with nested-PCR. (Abstr.) Phytopathol. Mediterr. 40:S480.

17. Fourie, P., and Halleen, F. 2004. Occurrence of grapevine trunk disease pathogens in rootstock mother vines. Australas. Plant Pathol. 31:425-426.

18. French-Monar, R. D., Jones, J. B., and Roberts, P. D. 2006. Characterization of Phytophthora capsici associated with roots of weeds on Florida vegetables farms. Plant Dis. 90:345-350.

19. Gams, W. 2000. Phialophora and some similar morphologically little-differentiated anamorphs of divergent ascomycetes. Stud. Mycol. 45:187-199.

20. Gardes, M., and Bruns, T. D. 1993. ITS primers with enhanced specificity for Basidiomycetes: application to the identification of mycorrhizae and rusts. Mol. Ecol. 2:113-118.

21. Gramaje, D., Armengol, J., Salazar, D., López-Cortés, I., and García-Jiménez, J. 2009. Effect of hot-water treatments above $50^{\circ} \mathrm{C}$ on grapevine viability and survival of Petri disease pathogens. Crop Prot. 28:280-285.

22. Gramaje, D., García-Jiménez, J., and Armengol, J. 2010. Field evaluation of grapevine rootstocks inoculated with fungi associated with Petri disease and esca. Am. J. Enol. Vitic. 61:512-520.

23. Gramaje, D., Mostert, L., and Armengol, J. Characterization of Cadophora luteo-olivacea and C. melinii isolates obtained from grapevines and environmental samples from grapevine nurseries in Spain. Phytopathol. Mediterr. In press.

24. Halleen, F., Crous, P. W., and Petrini, O. 2003. Fungi associated with healthy grapevine cuttings in nurseries, with special reference to pathogens involved in the decline of young vines. Australas. Plant Pathol. 32:47-52.

25. Halleen, F., Fourie, P. H., and Crous, P. W. 2006. A review of black foot disease of grapevine. Phytopathol. Mediterr. 45:S55-S67.

26. Halleen, F., Mostert, L., and Crous, P. W. 2007. Pathogenicity testing of lesser-known vascular fungi of grapevines. Australas. Plant Pathol. 36:277285.

27. Halleen, F., Schroers, H. J., Groenewald, J. Z., and Crous, P. W. 2004. Novels species of Cylindrocarpon (Neonectria) and Campylocarpon gen. nov. associated with black foot disease of grapevines (Vitis spp.). Stud. Mycol. 50:431-455.

28. Halleen, F., Van Niekerk, J., Mostert, L., Fourie, P., and Crous, P. W. 2005. Trunk disease pathogens associated with apparently healthy nursery grapevines. Wineland July:79-81.

29. Harrington, T. C., and McNew, L. 2003. Phylogenetic analysis places the Phialophora-like anamorph genus Cadophora in the Heliotales. Mycotaxon 87:141-151.

30. Hidalgo, L. 2002. Tratado de Viticultura General, 3rd ed. Ediciones MundiPrensa, Madrid.

31. Hollowell, J. E., Shew, B. B., Cubeta, M. A., and Wilcut, J. W. 2003. Weed species as hosts of Sclerotinia minor in peanut fields. Plant Dis. 87:197199.

32. Larignon, P., and Dubos, B. 1997. Fungi associated with esca disease in grapevine. Eur. J. Plant Pathol. 103:147-157.

33. Manning, M. A., and Munday, D. C. 2009. Fungi associated with grapevine trunk disease in established vineyards in New Zealand. Phytopathol. Mediterr. 48:160-161.

34. McKinney, H.H. 1923. A new system of grading plant diseases. J. Agric. Res. 26:195-218.

35. Mostert, L., Groenewald, C. J., Sumerbell, R. C., Gams, W., and Crous, P. W. 2006. Taxonomy and pathology of Togninia (Diaporthales) and its Phaeoacremonium anamorphs. Stud. Mycol. 54:1-115.

36. Mugnai, L., Graniti, A., and Surico, G. 1999. Esca (black measles) and brown wood-streaking: two old and elusive diseases of grapevines. Plant Dis. 83:404-418.

37. Oliveira, H., Rego, M. C., and Nascimento, T. 2004. Decline of young grapevines caused by fungi. Acta Hortic. 652:295-304.

38. Overton, B. E, Stewart, E. L., and Wenner, N. G. 2005. Molecular phylogenetics of grapevine decline fungi from Pennsylvania and New York. Phytopathol. Mediterr. 44:90-91.

39. Petit, E., and Gubler, W. D. 2005. Characterization of Cylindrocarpon species, the cause of black foot disease of grapevine in California. Plant Dis. 89:1051-1059.

40. Petit, E., and Gubler, W. D. 2007. First report of Cylindrocarpon liriodendri causing black foot disease in California. Plant Dis. 91:1060.

41. Rego, C., Oliveira, H., Carvalho, A., and Phillips, A. 2000. Involvement of Phaeoacremonium spp. and Cylindrocarpon destructans with grapevine decline in Portugal. Phytopathol. Mediterr. 39:76-79.

42. Retief, E., McLeod, A., and Fourie, P. H. 2006. Potential inoculum sources 
of Phaeomoniella chlamydospora in South African grapevine nurseries. Eur. J. Plant Pathol. 115:331-339.

43. Ridgway, H. J., Steyaert, J. M., Pottinger, B.M., Carpenter, M., Nicol, D., and Steward, A. 2005. Development of an isolate-specific marker for tracking Phaeomoniella chlamydospora infection in grapevines. Mycologia 97:1093-1101.

44. Rolshausen, P. E., Wilcox, W., and Baumgartner, K. 2010. Distribution and occurrence of fungi associated with grapevine trunk diseases in northeastern American vineyards. Phytopathol. Mediterr. 49:105.

45. Rooney, S. N., Eskalen, A., and Gubler, W. D. 2001. Recovery of Phaeomoniella chlamydospora and Phaeoacremonium inflatipes from soil and grapevines tissue. Phytopathol. Mediterr. 40:S351- S356.

46. Rooney-Latham, S. 2005. Etiology, epidemiology and pathogen biology of Esca disease of grapevines in California. Publ. No. AAT 3191148, PhD dissertation, University of California, Davis.

47. Schroers, H. J., Zerjav, M., Munda, A., Halleen, F., and Crous, P. W. 2008. Cylindrocarpon pauciseptatum sp. nov., with notes on Cylindrocarpon species with wide, predominantly 3-septate macroconidia. Mycol. Res. 112:82-92.

48. Sheck, H. J., Vasquez, S. J., and Gubler, W. D. 1998. First report of blackfoot disease, caused by Cylindrocarpon obtusisporum, of grapevine in California. Plant Dis. 82:448.

49. Sidoti, A., Buonocore, E., Serges, T., and Mugnai, L. 2000. Decline of young grapevines associated with Phaeoacremonium chlamydosporum in Sicily (Italy). Phytopathol. Mediterr. 39:87-91.

50. Tegli, S., Bertelli, E., and Surico, G. 2000. Sequence analysis of ITS ribosomal DNA in five Phaeoacremonium species and development of a PCRbased assay for the detection of P. chlamydosporum and P. aleophilum in grapevine tissue. Phytopathol. Mediterr. 39:134-149.

51. Whitelaw-Weckert, M. A., Nair, N. G., Lamont, R., Alonso, M., Priest, M J., and Huang, R. 2007. Root infection of Vitis vinifera by Cylindrocarpon liriodendri in Australia. Australas. Plant Pathol. 36:403-406.

52. Whiteman, S. A., Jaspers, M. V., Stewart, A., and Ridgway, H. J. 2002. Detection of Phaeomoniella chlamydospora in soil using species-specific PCR. N.Z. Plant Prot. 55:139-145.

53. Whiting, E. C., Khan, A., and Gubler, W. D. 2001. Effect of temperature and water potential on survival and mycelial growth of Phaeomoniella chlamydospora and Phaeoacremonium spp. Plant Dis. 85:195-201.

54. Wisler, G. C., and Norris, R. F. 2005. Interactions between weeds and cultivated plants as related to management of plant pathogens. Weed Sci 53:914-917.

55. Zanzotto, A., Autiero, F., Bellotto, D., Dal Cortivo, G., Lucchetta, G., and Borgo, M. 2007. Occurrence of Phaeoacremonium spp. and Phaeomoniella chlamydospora in grape propagation materials and young grapevines. Eur. J. Plant Pathol. 119:183-192. 